\title{
Insurance Perspective on Talent Management and Corporate Social Responsibility: A Case Study of Nordic Insurers
}

\author{
Lara Johannsdottir ${ }^{1}$, Snjolfur Olafsson ${ }^{1} \&$ Brynhildur Davidsdottir ${ }^{2}$ \\ ${ }^{1}$ School of Business, University of Iceland, Reykjavik, Iceland \\ ${ }^{2}$ Faculty of Economics and Faculty of Environmental and Life Science, University of Iceland, Reykjavik, Iceland \\ Correspondence: Lara Johannsdottir, School of Business, University of Iceland, Gimli v/Saemundargotu, IS-101, \\ Reykjavik, Iceland. Tel: 354-660-0294. E-mail: laraj@hi.is
}

\author{
Received: November 11, 2013 Accepted: December 6, 2013 Online Published: February 25, 2014 \\ doi:10.5539/jms.v4n1p163 \\ URL: http://dx.doi.org/10.5539/jms.v4n1p163
}

\begin{abstract}
Insurers are facing a problem of attracting new talent. They are competing with other industries for talent while clients simultaneously demand more service from insurers. At the same time, the industry is regarded as 'un-sexy', having poor reputation, and the talent pool is limited. The aim of this paper is to explore whether corporate social responsibility/sustainability emphasis can be used to attract talent to the insurance sector. The paper is based on a multi-case study including 16 Nordic non-life insurance companies, focusing on the environmental factor of corporate social responsibility or environmental sustainability, depending on the company's terminology. Qualitative methods were used to collect data, including 74 interviews with insurance executives and specialists. The paper suggest that focus on corporate social responsibility can be an enabling condition when attracting talent, i.e. if companies have a higher agenda than gaining more profit today than they did yesterday. Running a successful business requires companies to recognize the trends that will alter their business environment. If they incorporate and deal with issues of key concern for their future employees they are more likely to succeed in attracting talent.
\end{abstract}

Keywords: insurance, corporate social responsibility, talent management, employee, missing link

\section{Introduction}

\subsection{The Problem of Attracting Talent to the Insurance Sector}

To gain competitive advantage, and attain future success, the prime differentiator is believed to be the right talent (KPMG, 2012), but talent can be seen as "giftedness, individual strength, (meta-) competency, high potential, and high performance" employees (Meyers, van Woerkom, \& Dries, 2013, p. 306). Shortage of talent is expected to be a critical issue in the coming decade, meaning that talent management is of great importance (Mcdonnell, 2011). In Europe managing talent is considered to be one of the major human resource challenges businesses are confronted with, according to a survey carried out among 1,350 executives from 27 European countries (Strack et al., 2007). Talent management is recognized as a strategic issue for businesses (Boudreau \& Ramstad, 2005; Collings \& Mellahi, 2009; Lengnick-Hall, Lengnick-Hall, Andrade, \& Drake, 2009), and it is therefore of concern if and how organizations or industries deal with talent shortage. This is despite the global economic downturn and subsequent downsizing of companies' operations and workforce leading to higher unemployment rates (Tarique \& Schuler, 2010; Tymon, Stumpf, \& Doh, 2010).

Research regarding recruiting of talent is receiving the attention of researchers (Breaugh, 2008). However, the literature on corporate social responsibility (CSR) and talent management is limited. Few publications suggest that CSR emphasis assimilates legitimacy, therefore offering opportunities to attract and retain employees (Bhattacharya, Sen, \& Korschun, 2008), because of its intrinsic rewards influencing job satisfaction (Tymon et al., 2010). It is suggested that employer brand, companies' values, and culture are of importance for potential employees (Insurance Journal, 2013). The 'individual difference' hypothesis (Saks, 2005) may explain why employees choose some companies over others, for instance when job openings with important attributes (e.g., work ethics) receive their attention (Breaugh, 2008).

The insurance sector, just as other industries, needs to rethink priorities and strategies for growing and replenishing their personnel, as replacement of younger employees is steadily diminishing (Deloitte 
Development LLC, 2007). The sector has acknowledge the issue related to retaining and attracting new talent, if the industry is to be advanced in the global economy (Deloitte Development LLC, 2007; The Geneva Association, 2013), therefore calling for research on how to attract new talent in a globalized environment (Courbage, 2013; The Geneva Association, 2012, 2013).

This study offers a micro-level analysis (i.e., individuals) of recruitment possibilities within insurance companies, based on Nordic insurance case study data, but these types of CSR studies are particularly lacking (Aguinis \& Glavas, 2012). In light of insurers' issues in recruiting talent our research questions are:

- Is something inherent in CSR/sustainability emphasis that might help insurers dealing with the issue of talent management? If so, what?

The structure of the article is as follows. In section (2) we discuss the theoretical perspective on talent shortage and talent management, including a discussion about talent shortage within the insurance industry, and elements related to CSR/sustainability and talent-related issues. In section (3) we discuss the research methods. Our results are introduced in section (4) which discusses CSR and talent management within the Nordic insurance sector. Section (5) covers discussion and conclusion.

\subsection{Theoretical Perspective on Talent Shortage and Talent Management}

The term talent management gained recognition after McKinsey \& Company published the study, "War for talent” in 1997, emphasizing employers' challenges in recruiting talented people because of labor market situations (Axelrod, Handfield-Jones, \& Michaels, 2002; Collings \& Mellahi, 2009). Talent management is often used interchangeably with terms such as "talent strategy", "human resource planning", and "succession management” (Lewis \& Heckman, 2006). The core elements of talent management (Collings \& Mellahi, 2009, p. 304) are to;

- develop activities and processes that in a systematic way identify key positions which differentially contribute to organization's sustainable competitive advantage;

- develop high potential and high performing incumbents to fill these roles;

- develop differentiated human resource architecture necessary to facilitate filling these positions with competent incumbents and to ensure their continued commitment to the organization.

Organizations outclassing others in talent management master 1) internal fit, including attracting, selecting, developing, and retaining talent, 2) cultural fit aligning internal fit with companies culture, and 3) strategic fit of companies business strategy and long term goals (Stahl et al., 2007).

The term talent management has been separated into a high-level hierarchy of components (Lewis \& Heckman, 2006). According to Lewis and Heckman (2006) the first level deals with companies' strategy and sustainable competitive advantages, the second level deals with strategy implication for talent, the third level focuses on talent pool strategy, the forth level with talent management systems, and the fifth level with talent practices. Four streams of talent management have, furthermore, been defined; (1) human resource management or talent management focusing on recruitment, development of leaders, and succession planning, (2) development of the talent pool for example by projecting needs of employees, (3) managing talented people and top performers (Lewis \& Heckman, 2006), and (4) critical positions that may have an impact on firms' competitive advantage (Collings \& Mellahi, 2009; Huselid, Beatty, \& Becker, 2005). Collings and Mellahi (2009) suggest that companies start by identifying pivotal positions to fill, but these position contribute to firms performance, see figure 1. These positions are filled with talent from the talent pool. The talent pool exists of high potential, high performing existing (internal) and potential (external) employees. Firms' performance then depends upon work motivation, commitment to the organization, and extra role behavior of those filling the pivotal positions. 


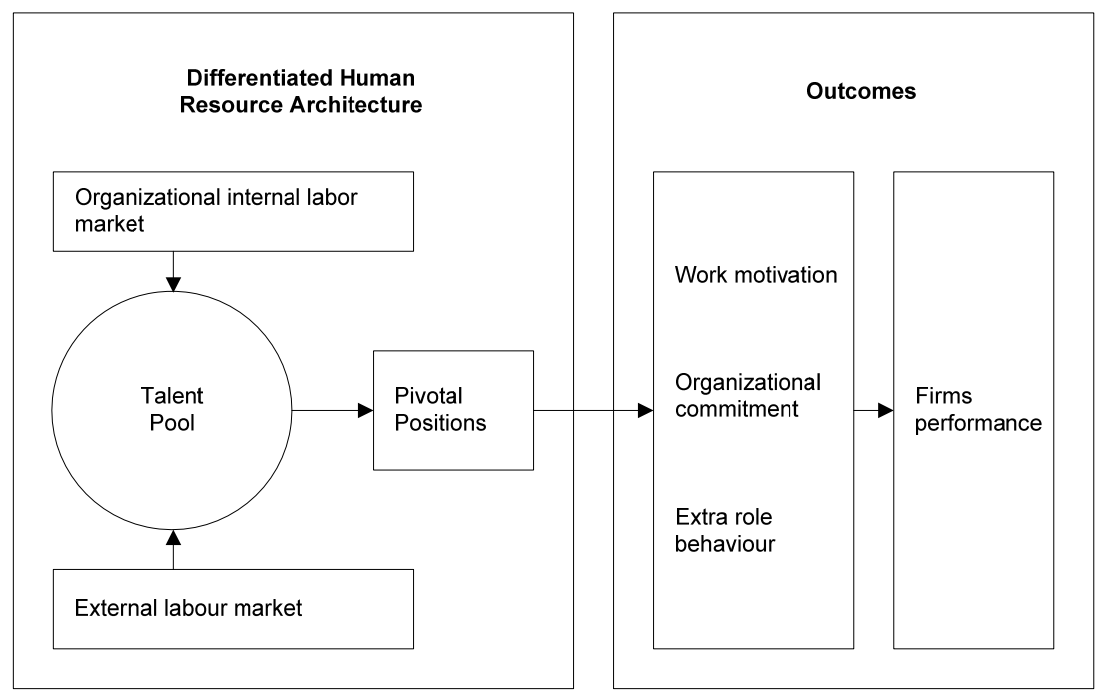

Figure 1. Strategic talent management (Collings \& Mellahi, 2009)

Attracting, retaining, and managing talent is of importance for companies operating in a highly competitive, complex, global, dynamic, and volatile environment, for reasons of talent mobility and shortage of competent young employees, thus being of strategic and growing importance (Beechler \& Woodward, 2009; Farndale, Scullion, \& Sparrow, 2010; Mcdonnell, 2011; Tymon, et al., 2010; Vaiman, 2010). With this respect, academic scholars (Boudreau \& Ramstad, 2005; Collings \& Mellahi, 2009; Lewis \& Heckman, 2006) suggest that companies worldwide will have to deal with greater competition in attracting, retaining, and developing talent needed for competitive advantage and business success. Although particularly important for multinational enterprises (MNEs), in need of global staffing (Collings \& Scullion, 2009; McDonnell, Lamare, Gunnigle, \& Lavelle, 2010), talent management issues are also becoming of great importance for small and medium-sized enterprises (SMEs) because of their rapid internationalization (Scullion \& Brewster, 2001).

Demographic trends and globalization, decreasing birth rate, aging population, immigration, educational trends and skill gaps are factors influencing talent shortage (Athey, 2004; Beechler \& Woodward, 2009; Lamb \& Sutherland, 2010; Stahl et al., 2007). Related issues are an exhausted and demoralized workforce lacking commitment to their workplace, having to do with previous downsizing, displeasure with jobs, demands from employers, and technologies keeping employees on the alert around the clock (Athey, 2004).

Global competition for talent is expected to increase (Farndale et al., 2010). Study of Stahl, et al. (2007) suggest that in emerging markets, including China and India, the issue relates to the shortage of graduates with skills adequate for multinational organizations. More specifically, there is a shortage of people with language skills, leadership potential, and experienced managers with suitable functional capabilities (Lane \& Pollner, 2008) educated in accounting, business, finance, and engineering (Farrell \& Grant, 2005). Other issues related to talent shortage and recognized by Stahl (2007) are job mobility, meaning of jobs, and workforce requiring flexibility seeking a balance between their work and personal circumstances (Athey, 2004). One of the hardest challenges recognized is to identify the talent early on, give employees important roles, meaningful assignments, and development opportunities (Spencer Stuart, 2007). The issue is recognized by human resource experts and consultants, and academics (Tarique \& Schuler, 2010).

\subsection{Talent Shortage and Insurers}

In the fifteenth annual global CEO`s survey carried out by PricewaterhouseCoopers (PwC) among more than 120 insurance CEOs around the world, approximately 60 percent claimed that shortage of skills threatens growth potentials, nearly 50 percent state that it is harder to retain and recruit good talent, and more than 30 percent affirm that they have not been able to pursue market opportunities because of this issues (Insurance Daily, 2012; PwC, n.d.). This suggests that a talent drain can influence possibilities for the business expansions of insurers. Due to the talent issue, more than 50 percent of the CEOs claim unexpected pay inflation (Insurance Daily, 2012).

A similar study has been carried out by KPMG among 102 insurance executives from large United States-based insurance companies. The study highlights the importance of having the right talent, as insurers need to "do more 
with fewer resources” (KPMG, 2012, p. 5). The study reveals that 40 percent of the executives plan to increase focus on performance management, 39 percent on succession planning, and 35 on training. Furthermore, those stating that lack of talent were a barrier to growth rose from 5 percent in the 2011 survey, to 16 percent in 2012 survey (KPMG, 2012).

Insurance talent shortage relates to expert knowledge, such as analytical and underwriting skills (PricewaterhouseCoopers LLP, 2012; Yoder, Rao, \& Bajowala, 2012). In particular there is a need for talent able to analyze and draw conclusions from big data, (PricewaterhouseCoopers LLP, 2012), but as the consequences of climate change become more evident this will become a critical issue in terms of risk management, loss control, and pricing. Data analysis is also essential for gaining insights about customers, agents, and markets (Accenture, 2013). In emerging markets, there is a talent shortage in these areas, while issues with ageing underwriters is an issue in the developed world, as well as lack of a high-potential middle managers, senior level talent, and actuaries (Actuarial Post, 2011; Insurance Daily, 2012; The Indian Express, 2012; Yoder et al., 2012).

The insurance sector is not regarded attractive for graduates to enter (Accenture, 2013); ranking in the 97th place out of 100 least-attractive industries for college graduates (Insurance Journal, 2013). Many factors explain this outcome, including the financial crisis and subsequent economic conditions, increased regulatory supervision, scandals, reputational damage, and customers mistrust (PricewaterhouseCoopers LLP, 2011; Risk Management, 2013), a relatively small talent pool because of low industry recognition in the society (The Geneva Association, 2012), and aging workforce (Activetics, 2013), and generational differences (Deloitte Development LLC, 2007).

Insurers can deal with the talent shortage in various ways, e.g. find hidden talents within their own organizations, raise awareness among students about carreer opportunities within the sector, work with labor market intermediaries, use social media venues and word-of-mouth, attracting and retaining more women and older workers, use more non-financial awards, set compensation limits for executive talents, and seek talent across industries (Accenture, 2013; Insurance Journal, 2013; PricewaterhouseCoopers LLP, 2011). They can also focus on what future employees expect. For instance, in a youth conference in 2009, 180 student leaders from across Canada focused on how different sectors might become more sustainable, in order to attract future employees. Insurers should, according to the student leaders, focus on climate change mitigation and adaptation, protect water, fight poverty, and advance human rights, engage in the community and contribute to social development, caring for consumers and employees, and ensure that insurance companies are managed properly (Network for Business Sustainability, 2010). Focus on CSR is believed to increase loyalty and engagement among employees, with the potential of reducing turnover rates, as well (Risk Management, 2013).

\subsection{CSR/Sustainability and Talent Related Issues}

There is a noticeable lack of research on the link between CSR/sustainability and talent management (Kim \& Scullion, 2011), particularly global talent management, defined as efforts of attracting, selecting, developing, and retaining talented employees on a global scale (Stahl et al., 2007). There are a few exceptions, including a study on CSR effects on attracting potential employees (Greening \& Turban, 2000), and employees' reactions, emotions, attitudes, and behaviors to social responsibility (Rupp, Ganapathi, Agulera, \& Williams, 2006), suggesting that more theoretical development is needed in this field. CSR practice has been shown to be a predictor of organizational commitment (Maignan \& Ferrell, 2001), influencing outcomes such as employee's productivity, motivation, absenteeism, and turnover rates, although the ethical-legal dimension of CSR has the greatest influence on organizational commitment (Dhanesh, 2010).

Empirical findings of the positive relations between CSR and financial performance exist (GEMI, 1998, 2001, 2004; Haanaes et al., 2011; Hart \& Milstein, 2003; Lovins, 2007; Porter \& van der Linde, 1995), but what role employees have to play in delivering these benefits is, to a much lesser degree, known. One empirical study surveying more than 10,000 employers and employees from 5,220 French firms shows that companies adopting international environmental standards, such as ISO 14001, gain 16 percent higher labor productivity than firms that have not implemented these standards (Delmas \& Pekovic, 2013). According to Delmas and Pekovic (2013) increased labor productivity rest on more employees training and collaboration across the companies.

The World Business Council for Sustainable Development (WBCSD) identifies the ties between sustainable development, business strategy, and employees. The logic is to involve employees in addressing sustainability issues, as many employees are concerned with climate change, environmental degradation, poverty, health, and other issues. According to WBSCD the business case for employees' engagement is (World Business Council for Sustainable Development, 2010);

1) Behavioral change resulting in cost savings, risk reduction, reputation enhancement, and innovation arising from new work methods, new skills, and new goals. 
2) Innovation resulting in new ideas and cost savings, coming from all over the business if employees make the connection between sustainability issues mattering to them, their own work, their community, the planet, and the business.

3) Attracting and retention of talent facilitated through sustainability commitment. Studies have shown that top graduates, e.g. MBA graduates, are interested in sustainability commitments, and values of prospective employers. Employees also consider leaving companies not meeting such expectations.

4) Motivation and productivity encouraged if companies have purpose. If employees feel they are valued they will "go the extra mile" to solve problems, take initiative, help peers and customers, and work collaboratively. Sustainability emphasis can also bring people together, finding a common sense of purpose between employees from different geographical areas.

5) Brand reputation can be strengthened or damaged by employees, meaning that companies must emphasise the license to operate and sustainability to protect it.

“... firms must offer more than a good paycheck ... and investment in social capital can bring richer returns than many technology investments (Athey, 2004, p. 11)”. The key effects of sustainability/CSR emphasis are 1) recruiting and retaining people is easier, 2) engagement and productivity improves, and 3) expectations may rise which can have negative consequences if companies do not live up to their intentions (Brokaw, 2009).

It has been suggested that job applicants can be attracted because of organizations' social programs and policies, as it signals firms working conditions. A statistical analysis of this relationship has been carried out showing that firms with higher corporate social performance (CSP), are more attractive because of their positive reputation, than firms with lower CSP scores, which may result in a potential competitive advantage (Greening \& Turban, 2000; Turban \& Greening, 1996). It has furthermore been demonstrated that CSP positively related to organizations attractiveness for people seeking jobs, if the candidates have high levels of job options meaning that this can be a way to attract high level candidates (Albinger \& Freeman, 2000). Three underlying CSP processes and mechanism have been identified; 1) pride in being affiliated with the organization, 2) a perceived fit with the organizational values, and 3) expectation about working conditions within the organization (Jones, Willness, \& Madey, 2013).

Existing employees are also influenced by how they perceive their organizations CSR emphasis. This affects their commitments, having as much influence as job satisfaction (Brammer, Millington, \& Rayton, 2007). This mainly relates to so-called "external CSR", meaning reputation, image, contribution to community, philanthropy, and ethical stance towards stakeholders (Carroll, 1979), although these emphases only provide indirect benefits to employees (Brammer et al., 2007). This suggests that CSR emphasis can have positive intrinsic motivation impacts, but intrinsic rewards are viewed as critical factors in employees' satisfaction with the organization as carreer success, and retention (Tymon et al., 2010). Intrinsic motivations include positive feelings, passion, and pride, fulfilling employees experience and needs through their work (Bhattacharya et al., 2008; Quigley \& Tymon Jr, 2006), strengthening their commitment and loyalty to the organization (Branco \& Rodrigues, 2006). It is therefore suggested that CSR can be used to enhance employees' impression of intrinsic rewards, instead of relying solely on financial benefits (Vaiman, Scullion, \& Collings, 2012). Furthermore, using CSR/sustainability to motivate employees is more challenging to imitate than offering higher financial rewards (Tymon et al., 2010).

Penn, Schoen \& Berland Associates in collaboration with Burson-Marsteller, \& Landor, conducted an online survey with the general public in the United States in 2009. Their key findings suggest that the majority of respondents (56\%) think it makes a difference working for socially responsible companies. The responce rate is even higher for younger and wealthier respondents (61\%). The study suggest that respondents (40\%) are willing to sacrifice in terms of pay cuts, to work for socially responsible firms, meaning that social responsibility may affect the career decisions of talented people. The study also brings forth a difference between industries, meaning that social responsibility is more important in certain industries than others. In this respect, CSR is perceived as being of great importance for the finance sector, but the industry is perceived to have performed poorly in dealing with corporate social responsibility issues (Penn Schoen \& Berland Associates, Burson-Marsteller, \& Landor, 2009).

It should be noted that although jobs supporting environmental sustainability are highly valued, there is still an issue with creating, supporting, and defining the immediate environmental benefits of these jobs, what kind of skills are required, and what governmental policies will drive the growth of green jobs (World Economic Forum, 2011). 


\section{Method}

The paper is based on the PhD research of one of the authors. The purpose of the study was to examine Nordic non-life insurers' interest in, and response to, environmental issues. Although not the key aim of the study, talent management in relation to sustainability/CSR was brought up for discussion by some of the interviewees, therefore contributing to the so far limited research in this field. Glaser and Strauss (1967) state that; "[q]ualitative researchers begin their studies with minimal commitment to a priori assumptions and theory" (Taylor \& Bogdan, 1998, p 146), which was actually the case with the theme 'talent'. Instead, as suggested by Taylor \& Bogdan the findings emerged out of the data, and are shared through the data.

The research process included the following steps; 1) definition of research boundaries and case selection, 2) contacting potential companies, 3) field visits to gather data through interviewees, observation, secondary data etc., 4) analysis of data, and 5) member check, meaning a feedback from insurance specialists when required, and 6) writing of the findings.

The Nordic insurance sector was chosen because of the perceived forerunners role of the Nordic nations in protecting the nature (Magnúsdóttir, 2009; Norden, 2010; Nordic Council of Ministers, 2009), and as "global pioneers in sustainability and CSR” Gjølberg, M. (2013, p. 287).

In this case study, 2-4 of the biggest Nordic non-life insurance companies, nationally or regionally, in term of market share, were included, altogether 16 companies. The companies differ in terms of size, legal forms, ownership, and core focus. Table 1 includes information about the companies' different size and location, number of sites visited, number of interviews and interviewees, and participants observations, including visits to insurers' suppliers and claims partners.

Table 1. Statistical information about the companies and interviews

\begin{tabular}{ccccc}
\hline $\begin{array}{l}\text { Company size } \\
\text { and location }\end{array}$ & Number of sites visited & $\begin{array}{c}\text { Number of } \\
\text { interviews }\end{array}$ & $\begin{array}{c}\text { Number of } \\
\text { interviewees }\end{array}$ & $\begin{array}{c}\text { Participants' } \\
\text { observations }\end{array}$ \\
\hline $\begin{array}{c}\text { Employees }<\mathbf{2 5 0} \\
\text { Aland }\end{array}$ & 2 & & & 1 \\
Faroe Island & 2 & 7 & 9 & 0 \\
Iceland & 4 & 6 & 6 & 2 \\
Employees $<$ 7,000 & & 14 & 16 & 1 \\
Denmark & 2 & 4 & 4 & 1 \\
Finland & 2 & 9 & 10 & 2 \\
Norway & 2 & 8 & 9 & 0 \\
Sweden & 3 & 14 & 20 & 7 \\
\hline
\end{tabular}

Table 2 lists insurance companies in Åland, Faroe Islands, and Iceland. Two of these companies are small, employing fewer than 50 employees, and six are medium sized, employing between 50 and 249 persons (Eurostat \& Schmiemann, 2009). All of these companies allowed visits to their sites, permitting access to executives and specialists for interviewing.

Table 2. Small and medium sized companies included in the study

\begin{tabular}{lll}
\hline Åland & Faroe Islands & Iceland \\
\hline Ålands Ömsesidiga & Trygd & Vátryggingafélag Í́slands \\
Alandia Corporations & Tryggingarfelagið Føroyar & Sjóvá-Almennar \\
& & Tryggingamiðstöðin \\
& & Vörður \\
\hline
\end{tabular}

Table 3 lists insurance companies operating in Denmark, Finland, Norway and Sweden. These companies are large, with 250 or more persons employed, in this case between 400 and 7 thousand employees. Companies marked with the same gray-scale color belong to the same insurance group, meaning that these are 12 individual insurance entities. Of these 12 insurance companies/groups, 8 allowed primary data to be collected through interviewees at their sites. 
Table 3. Insurance companies operating on the mainland (large companies)

\begin{tabular}{llll}
\hline Denmark & Finland & Norway & Sweden \\
\hline Codan & IF & IF & Länsförsäkringar \\
Alm Brand & Pohjola & Gensidige & Folksam \\
TrygVesta (now Tryg) & Tapiola & Sparebank 1 & IF \\
TopDanmark & Fennia & TrygVesta (now Tryg) & Trygg-Hansa \\
\hline
\end{tabular}

\subsection{Data Collection}

Field note framework was developed and filled out for each interview. It included the following topics; 1) access to the company and pre-interview communication, 2) entering the field, 3) description of the field (e.g. photos), 4) information about interviewee, 5) activity (if any), 6) office equipment and layout (e.g. drawings or photos), 7) events (if any), 8), timeframe, 9) word-by-word interview transcript, 10) leaving of the site, 11) feelings, thoughts and reflections about the interview or the research in general. Research diary, memos, and spreadsheets are a part of the data collected and analyzed. The latest information presented at a Nordic insurance climate conference in September 2012 serves as an update to interview data.

Data was collected in the participants' natural setting, where the researcher was the key instrument in the data collection process (Creswell, 2007). Companies' sites were visited to interview insurance executives and specialists. Interviews took place from September 2009 through September 2010. In total, 74 persons were interviewed. Participant observations were eight, including a group meeting, a visit to a supplier, sightseeing of a new facility and participation in the Nordic Insurance Climate Conferences (NICC) in 2009, and 2012. Furthermore, 6 interviews with outside specialists were carried out. Interviews transcribed and stored in field notes, amount to 2,614 pages. For triangulation purposess multiple sources of data, such as companies' presentations, reports, information on websites etc. were used.

\subsection{Analysis of Data}

The analytical process started parallel to data collection. Interview data was arranged according to country, company, and interviewees. During and after the transcription of each interview and participant observation, notes were read thoroughly line-by-line to see which themes emerged from the data. This was done as an open coding process, not guided by predetermined codes. In a parallel process mind-maps for the companies were created in Mindjet Mind Manager 8 to keep track of themes, clustering ideas and providing details to support the themes (Creswell, 2007). Initial codes (Creswell, 2007) emerging, were used in classifying themes in other mind-maps as well. Figure 2 shows an example of a MindMap of value themes from the interviews.

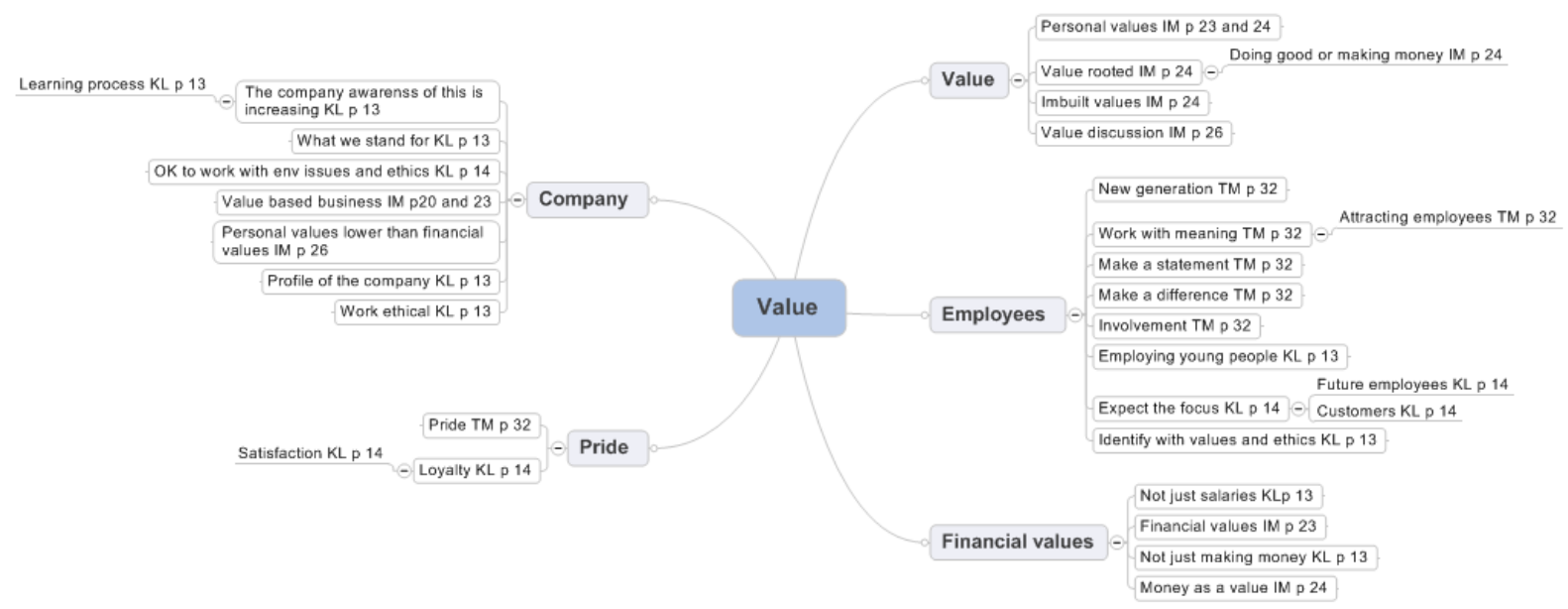

Figure 2. Mindmap of value related themes

Multiple methods were used for data analysis, including theme analysis, content analysis, cross-case analysis and constant comparative method (Glaser \& Strauss, 1967; Kvale \& Brinkmann, 2009; Stake, 1998; Yin, 2009). Interviewees used different terms to describe their companies' actions, including CSR, sustainability, corporate responsibility, and climate change. For the sake of simplicity we use the term CSR. 


\section{Results: CSR and Talent Management within the Nordic Insurance Sector}

Discussion around CSR and talent management within the Nordic insurance sector is structured around the following themes brought up by interviewees; 1) the CSR business case, 2) companies visions, values, and talent management, and 3) barriers insurers needs to overcome in order to benefit from CSR emphasis in talent management.

\subsection{The CSR Business Case}

The corporate social responsibility of insurers came forth in some of the interviewees, mainly discussed from the perspective that the insurance business is more than a business. This is due to the nature of the business of protecting people and various types of properties, thus providing peace of mind and security. When the worst happens, insurance companies help put things right so people do not have to start all over again empty-handed. There are, therefore, both financial and social elements inherent in the insurance business, which should enable insurers to demonstrate their CSR commitments to various stakeholders if emphasized in the daily business. Quoting two Icelandic interviewees:

- I always think insurance is more than a business. The social component should also be rich. Of course insurance has to be profitable, but one should never forget the social aspect of the business.

- It is role of insurance to care for the valuables in peoples' live and support them when damage is done.

It was suggested by interviewees that environmental and climate priorities can be used as a key differentiator, due to the otherwise similar pricing and policy structure of insurance products, to gain competitive advantages. As the business case for CSR becomes clearer, and benefits are recognized, so does the ambition to become a leader in this area. Several of the biggest companies in the study therefore aim for a leading role in case of CSR emphasis.

- We would like others to follow us; we want to be a frontrunner (Danish interviewee).

- ... climate change where we have role which is at least unique in Norway, maybe even in Northern Europe (Norwegian interviewee).

- We do quite a lot and when comparing with other companies, I think we are if not best in class, [we are] among the better ones (Swedish interviewee).

- We can't be the second one, we want to lead and stay there (Finnish interviewee).

Among the reasons given for why environmental actions may bring about strategic benefits is because it will attract potential business partners, large business clients, and employees, particularly the younger generation. This therefore strengthens the business case for CSR, although the relationship with the revenue side or the bottom line performance is not as obvious as in the case of selling products or services.

- If you work in these areas you make you more attractive to business partners and more attractive to large business clients. It makes you more attractive to employees, as well. So that's why we go more into these areas actually (Danish interviewee).

\subsection{Companies Visions, Values, and Talent Management}

Interviewees explained the importance of company's vision of a better world, higher agenda or purpose instead of merely pursuing financial gains. The emphasis of environmental responsibility and responsibility for workers, stakeholders and communities can then help companies attract talent. Pure focus on financial gains was seen as old-fashioned and outdated, in a world and societies dealing with great deal of social and environmental issues. Interviewees suggested that it matters to future employees what the company stands for meaning that branding is of importance. Pride was mentioned as a factor for employees and people choosing a company to work for, but pride can have an impact on employees' loyalty. It is therefore important how companies profile themselves to existing employees. By choosing a company with values that fits employees' personal values, they feel they can make a contribution, not just for the company but for society at large. Furthermore, if companies want to attract employees in a tough competition for the 'best and the brightest', focus on what really matters to potential employees may be the factor that distinguishes between future employers.

- If you look at the employee side, employees want to work, at least the new generations, where it is not just about making money but it is work with meaning. You know they want to be proud of where they are working, so that's why corporate responsibility and the environmental side are so important as well. You want to make a statement, you want to be involved, and you want to make sure that you make a difference (Danish interviewee). 
- I think also that the company has been aware that, if you are going to employ young people they want to identify themselves with the company's ethics and values as well. Not just salaries, also the ethics and what we stand for. And that's also something you have to use to profile yourself as a company that actually takes care of them and environment and works ethically (Swedish interviewee).

- The only opinion we have is that we want to make more money than last year. I think that is out of time. I think that employees they don't accept that. They don't want to enter a job at a company which is just there to make more money than last year (Danish interviewee).

Innovative and visionary leaders sharing their vision, and companies' values, were seen as critical elements for success when integrating CSR emphasis into the business. Employees seem to sense right away if the leadership commitment to CSR is not genuine, reflected in irony and skepticism about leadership actions, or inactions. It is therefore critical for leaders to commit to CSR whole-heartedly, and lead by example, if the effects are to be positive in influencing the commitment of current employees, and attracting new talent. Consistency between words and deeds is of utmost importance. If leaders do not set the course and show commitment themselves, not much will happen, and it is unlikely that the companies get recognized for thei CSR-related commitments and actions.

- You really need to have someone who say's "I do believe in this one", and we have seen this in our group (Swedish interviewee).

- .. it's more a question of values for [the company] actually for the time being; that we should be a responsible citizen, corporate citizen in order to be credible (Finnish interviewee).

- I think that basically we have in the steering committee; I mean the board of management there is basically doubt whether this [climate change] is real. I say that the attention haven't got to that point where we really consider this reality (Danish interviewer).

The importance of building awareness about CSR, engagement, and personal responsibility was discussed in relation to existing employees, but this was seen as critical if integration is to be successful, and can, among other things, influence job satisfaction, loyalty and commitment to the organization, and absenteeism. The companies use different means of building employees awareness, and gain employees commitment. This includes seminars, workshops, climate-weeks, online training, blogging on environmental issues, collecting ideas from employees, employees' participation in philanthropic activities of non-governmental organizations, and eco-driving lessons.

- We started to engage all employees. The first year we had something called climate week. Everyday there was a new subject which people should involve in. We had group meetings and they [employees] had questions. We were just trying to reason why the company is trying to make a difference when it comes to climate (Danish interviewee).

- I think the company did something smart when they arranged this climate package to involve all the employees, because it is the employees that pollute, the employee that fly and drive and use power and print and drink from bottles and so on. So you have to include the once which will get affected by all the measures and build some kind of ownership, and build an understanding why it is important (Norwegian interviewee).

To this point, management or employees do not have personal environmental or climate targets which influence their wage terms, except in one company where flat $\mathrm{CO} 2$ reduction targets have been introduced on divisional levels. This could, however, influence behavior, thus speeding up the development-although this is not the only motivation factor. Ethical motivation, reflecting concerns for the environment and the society, was also brought up by several of the interviewees.

- People do what they are asked to do and where they have incentives to do it - where they find taste of honey in their mouth when they succeed (Finnish interviewee).

- I think there should be a part of our group's individual annual targets. It should have something to do with environmental issues (Finnish interviewee).

What insurers encountered when raising awareness was a 'snowball effect', meaning increased interest creating internal pressure which they need to satisfy, otherwise credibility issues may occur. The snowball effect extends beyond the boundaries of the companies to suppliers, and sub-suppliers, e.g. in case of claims. Then again, this may have a positive impact on the image of firms, consequently making them more attractive for potential employees. 
- One challenge could be that of course when you start working with this knowledge that personal awareness [rise and] people ask more and more (Finnish interviewee).

- This is the cultural aspect. Since the company started "it's just getting bigger and bigger, like a snowball, and it will not stop now (Danish interviewee).

Many of the interviewees also claim that they receive positive feedback from their co-workers on how proud they are of working in a company which focuses on climate change and the environment, and such emphasis means a lot to them. A shift in mindset was mentioned as an achievement gained from raising awareness and gaining commitment from employees.

- What we have achieved is that I believe that the mindset is better than it has been. We are ready to invite people to work in this group and they come positively even though it is a work they have to do on top of their usual work. They are eager to start this and lots of small ideas have been provided (Finnish interviewee).

\subsection{Barriers to Overcome}

When companies start integrating CSR emphasis, employees may resist the changes as frequently know from change management initiatives. In the case of integrating CSR emphasis into the day-to-day business, if employees do not make the connection between their own jobs and the benefits of the companies, the environment or society they may obstruct actions. If the link is made evident, employees feel pride and engaged and the job becomes meaningful as they are making a difference on a larger scale than in their daily jobs.

- Normally they just look at the budget. We just said, you need to, within that budget, find the best solution when it comes to climate. After one year they understood why they should do it, and they were engaged to it, and actually they are proud of doing it and I think it gives the job more content. It feels like they are actually making a difference (Danish interviewee).

The role of external CSR communication is challenging for insurers, as they usually "stay under the radar". Therefore, their capability to address societal concerns is not always know to other stakeholders, meaning that they are, so-far, not gaining from CSR-related actions, e.g. in attracting talent.

- I think that we all are underestimating the role of the insurance companies. We are sort of giants that exist, but we don't really want to be seen. So now we're talking more about this and being invited authorities; we need you in order to come up with these carrots and whips as well (Swedish interviewee).

- Also because the nature of the business. So from our perspective it does not matter if it is climate change or just change in natural fluctuation in whatever. It will influence society and that means that we must be leading this discussion (Finnish interviewee).

\section{Discussion and Conclusions}

The nature of the insurance business in protecting properties and people's lives may suggest that CSR is inherent in the insurance business, providing insurers with an element that can be used to attract talent. Focus on CSR may therefore be used to create internal, cultural, and strategic fits (Stahl et al., 2007) between the nature of the business and attracting and retaining talent. This applies both to multinational insurance enterprises in need of global staffing (Collings \& Scullion, 2009; McDonnell et al., 2010), and small and medium-sized insurance companies because of their international ties (Scullion \& Brewster, 2001), being of strategic importance for an industry dealing with a talent shortage (Beechler \& Woodward, 2009; Boudreau \& Ramstad, 2005). The high-level hierarchy of components in talent management discussed by Lewis and Heckman (2006) is evident in the case study findings with respect to CSR, although the first two levels of companies' strategy and sustainable competitive advantages and strategy implication for talent are most critical when using CSR emphasis in attracting and retaining talent.

Because of the talent shortage within the insurance industry (Courbage, 2013; Deloitte Development LLC, 2007; The Geneva Association, 2013; Yoder, et al., 2012), the strategic talent management model (Collings \& Mellahi, 2009) presented previously is in many ways useful for understanding what contributes to the talent pool, and how pivotal positions, filled with high level candidates, can influence firms performance. The model is a one-way model, meaning that employees in pivotal positions can influence firms' performance. The model does not suggest that firms performance may influence how companies can fill pivotal positions, and influence to what extent they can fill their talent pools. We therefore suggest a modification of the model based on the potential benefits of CSR in talent management, see figure 3. The revised model is a two-way model, as we 
suggest a flow back and forth between the model's components. Starting from box furthest to the right, following the backward flow of the arrows to left, it suggests that companies with a strong triple line performance (people, profit, planet), based on their vision and commitments to CSR will be able to fill pivotal positions through a bigger talent pool filled up with people from their internal and external labor markets.

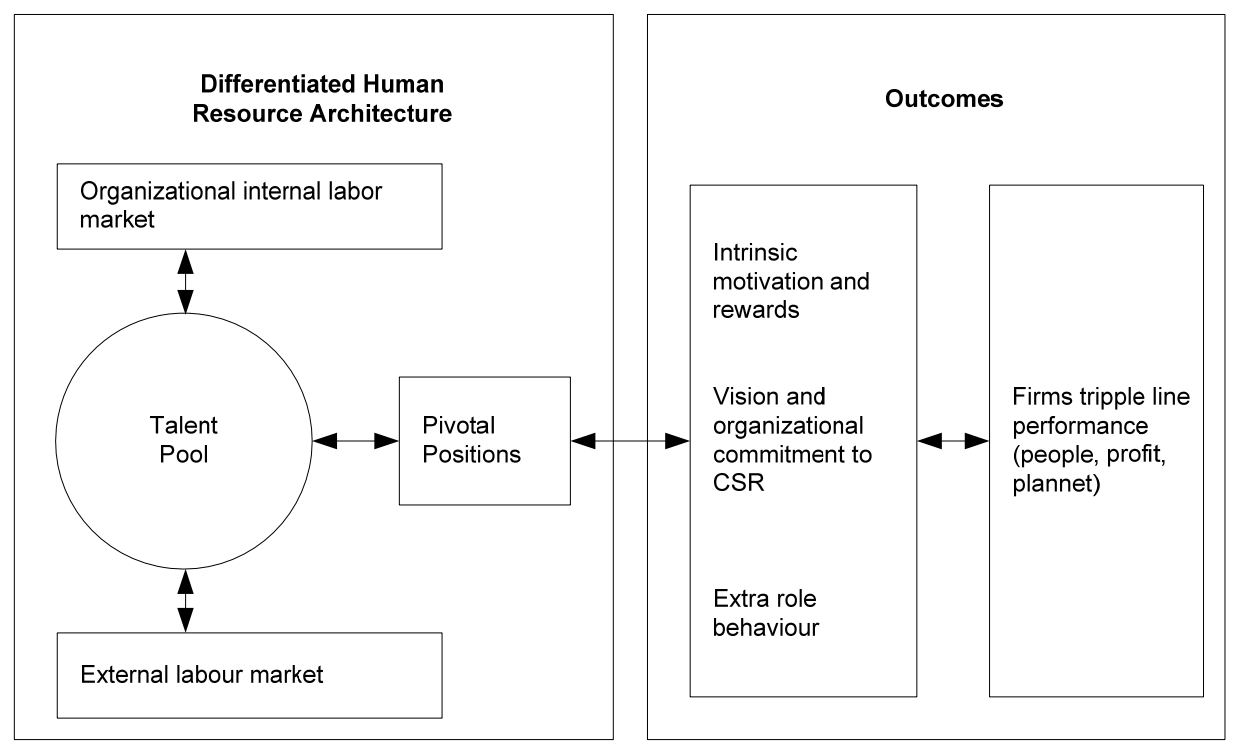

Figure 3. Strategic talent management of Collings \& Mellahi (2009) revised

Insurers' shyness as 'silent giants', with low industry recognition and attractiveness (The Geneva Association, 2012), is not the optimal method in talent management where the talent pool is steadily diminishing (Deloitte Development LLC, 2007). Furthermore, the industry is perceived as having performed poorly in dealing with CSR issues (Penn Schoen \& Berland Associates et al., 2009) therefore not utilizing the benefits of CSR emphasis. It appears that companies performing poorly in CSR matters may fail to benefit from using CSR to attract high level candidates (Albinger \& Freeman, 2000; Lewis \& Heckman, 2006), and use it to influence job satisfaction, carreer success, retention, emotions, attitudes, and behavior (Rupp et al., 2006).

Our study results indicate that CSR culture has an impact on the content richness of jobs, in the sense that it becomes work with meaning, engagement, employees pride and other intrinsic factors, therefore giving support to Bhattacharya et al. (2008) Quigley and Tymon Jr. (2006), and Jones et al. (2013) findings of intrinsic rewards influencing job satisfaction, and the potential of strengthening employees commitment and loyalty as suggested by Branco \& Rodrigues (2006), and Athey (2004). The snowball effect, and the internal pressure of taking actions, verifies Broakaw (2009) findings that if companies do not live up to their intentions, it may have negative consequences. Our study's findings furthermore indicate that WBSCD (2010) business case for employee engagement in sustainability applies to insurers, particularly attracting and retention, motivation, and brand reputation.

The insurance sector is a service sector, large and globalized, with a solid network of suppliers and claims partners. As such, it can be in a position to define and drive development of and support green jobs (World Economic Forum, 2011), and in that way pursuing future advancement, new market opportunities, and business expansion (Deloitte Development LLC, 2007; Insurance Daily, 2012; PwC, n.d.; The Geneva Association, 2013). Furthermore, companies differentiation based on CSR proposition is harder to imitate than financial compensations and benefits (Tymon et al., 2010; Vaiman et al., 2012), thus being of importance in a challenging and competitive business environment (Huselid et al., 2005).

Drawing from the literature, and interview data, our study suggests that insurers have two ways of using CSR as a contributing factor in solving the talent management issue. In figure 4, talent shortage is the issue insurers are confronted with. CSR can then be used as an enabling factor in solving the issue, both by attracting new talent, as well as in retaining and developing existing talent. Through CSR emphasis and actions, insurers gain and signal a positive brand reputation. This can be an important attribute for people seeking jobs, as it may fit their personal values, influencing their choice of future employer, in this case a company with a purpose. For current 
employees the signal can be equally strong, evident in intrinsic rewards employees gain, evident in pride, loyalty and engagement. In an industry considered to be one of the least attractive for graduate students, emphasizing through action that the insurance business is "more than a business" in the sense that it deals with global and local issues, may be an important factor in resolving the talent issue, thus contributing to competitive advantages of those companies recognizing that this is an important factor for the generation inheriting the global problems that previous generations have created.

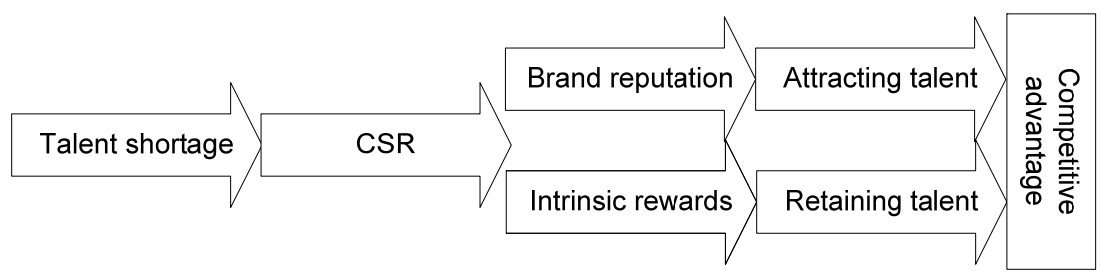

Figure 4. CSR as an enabling factor in solving the talent shortage

The paper offers contribution to the management, CSR, pro-environmental literature, and insurance literature although more theoretical development and empirical studies are needed. Advancement of talent management literature, with respect to CSR, is of importance as these types of studies have been developing at slow rate. Our study is based on anecdotal evidence, meaning that generalization is limited. Although the conclusion must be viewed in the light of the limitation of the study in terms of generalization, our findings suggest that insurers may look to CSR as one of the missing links in talent management based on the nature of their business, an issue that insurers are already confronted with. We believe that further research is needed, particularly, concerning if and how CSR can be used in helping companies resolve their talent shortage and talent management issues.

\section{Acknowledgements}

We wish to thank Nordic insurance experts and specialists for the permission to be interviewed and the anonymous referees for helpful suggestions that have substantially improved this paper. We would also like to thank those partly providing funds for the study, including Landsvirkjun Energy fund, Orkuveita Reykjavíkur Environmental and Energy fund, Erasmus Programme of Student Mobility for Study or Placement, Pálmi Jónsson Nature Conservation Fund, RioTintoAlcan Community fund, the Nordic Centre of Excellence for Strategic Adaptation Research (NORD-STAR), Nordic Climate change Adaptation research Network (NORDCLAD-Net, Nordic Climate Mitigation, Adaptation and Economic Policies (N-CMAEP) Network, School of Business University of Iceland, and SHÍ Student fund.

The research presented in this paper contributes to the Nordic Centre of Excellence for Strategic Adaptation Research (NORD-STAR), which is funded by the Norden Top-level Research Initiative sub-programme 'Effect Studies and Adaptation to Climate Change.

\section{References}

Accenture. (2013). Major Analytic talent shortage in Global Insurance industry. Retrieved from http://www.accenture-blogpodium.nl/latest-post/analytics-talent-insurance/

Activetics. (2013). Talent Shortage, A Key Business Risk-Allianz Global Corporate and Speciality. Retrieved from http://activetics.com.au/talent-shortage-a-key-business-risk-allianz-global-corporate-and-speciality/

Actuarial Post. (2011). Solvency II and Senior Level Talent Shortages Offer New Career Opportunites for Actuaries.

Retrieved https://www.ctnet.com/uploadedFiles/Consultants/BioNews/2011/KWT_ActuarialPost_072011_A4Por trait.pdf

Aguinis, H., \& Glavas, A. (2012). What We Know and Don’t Know About Corporate Social Responsibility: A Review and Research Agenda. Journal of Management, 38(4), 932-968. http://dx.doi.org/10.1177/0149206311436079

Albinger, H. S., \& Freeman, S. F. (2000). Corporate Social Perfornance and Attractiveness as an Employer to Different Job Seeking Populations. Journal of Business Ethics, 28(3), 243-253.

Athey, R. (2004). It's 2008: Do you know where your talent is? Why acquisition and retention strategies don't 
work. Deloitte Development from http://www.deloitte.com/assets/Dcom-UnitedKingdom/Local\%20Assets/Documents/UK_Consulting_ TalenMgtResearchReport.pdf

Axelrod, B., Handfield-Jones, H., \& Michaels, E. (2002). A new game plan for C players. Harvard Business Review, 2002(January), 8-88.

Beechler, S., \& Woodward, I. C. (2009). The global "war for talent”. Journal of International Management, 15(3), 273-285. http://dx.doi.org/10.1016/j.intman.2009.01.002

Bhattacharya, C. B., Sen, S., \& Korschun, D. (2008). Using Corporate Social Responsibility to Win the War for Talent. MIT Sloan Management Review, 49(2), 37-44.

Boudreau, J. W., \& Ramstad, P. M. (2005). Talentship, talent segmentation, and sustainability: A new HR decision science paradigm for a new strategy definition. Human Resource Management, 44, 129-136. http://dx.doi.org/10.1002/hrm.20054

Brammer, S., Millington, A., \& Rayton, B. (2007). The contribution of corporate social responsibility to organizational commitment. The International Journal of Human Resource Management, 18(10), 1701-1719. http://dx.doi.org/10.1080/09585190701570866

Branco, M. C., \& Rodrigues, L. L. (2006). Corporate Social Responsibility and Resource-Based Perspectives. Journal of Business Ethics, 69, 111-132. http://dx.doi.org/10.1007/s10551-006-9071-z

Breaugh, J. A. (2008). Employee recruitment: Current knowledge and important areas for future research. Human Resource Management Review, 18(3), 103-118. http://dx.doi.org/10.1016/j.hrmr.2008.07.003

Brokaw, L. (2009). Does Sustainability Change the Talent Equation? MIT Sloan Management Review, 51(1), 33-34.

Carroll, A. B. (1979). A three-dimensional conceptual model of corporate performance. Academy of Management Review, 4(4), 497-505.

Collings, D. G., \& Mellahi, K. (2009). Strategic talent management: A review and research agenda. Human Resource Management Review, 19(4), 304-313. http://dx.doi.org/10.1016/j.hrmr.2009.04.001

Collings, D. G., \& Scullion, H. (2009). Global staffing. International Journal of Human Resource Management, 20(6), 1249-1272. http://dx.doi.org/10.1080/09585190902909798

Courbage, C. (2013). Editorial. Insurance Economics Newsletter, 67(1), 1-26. Retreived from https://www.genevaassociation.org/media/178512/ga2013-ie67-courbage.pdf

Creswell, J. W. (2007). Qualitative inquiry and research design: Choosing among five approaches (2nd ed.). Thousand Oaks: Sage Publications, Inc.

Delmas, M. A., \& Pekovic, S. (2013). Environmental standards and labor productivity: Understanding the mechanisms that sustain sustainability. Journal of Organizational Behavior, 34, 230-252.

Deloitte Development LLC. (2007). Generational Talent Management for Insurers: Strategies to attract and engage Generation $Y$ in the U.S. insurance industry. New York: Deloitte \& Touche USA LLP. Retrieved from

http://www.deloitte.com/assets/Dcom-UnitedStates/Local\%20Assets/Documents/us_fsi_insurance_Ge nYtalentmngtt_may07.pdf

Dhanesh, G. S. (2010). The view from within: internal publics and CSR. Journal of Communication Management, 16(1). http://dx.doi.org/10.1108/13632541211197987

Eurostat \& Schmiemann, M. (2009). SMEs were the main drivers of economic growth between 2004 and 2006. Luxembourg: European Communities.

Farndale, E., Scullion, H., \& Sparrow, P. (2010). The role of the corporate HR function in global talent management. Journal of World Business, 45(2), 161-168. http://dx.doi.org/10.1016/j.jwb.2009.09.012

Farrell, D., \& Grant, A. (2005). Addressing China's looming talent shortage. McKinsey Quarterly, 4, 70-79. Retreived from http://www.mckinsey.com/insights/china/addressing_chinas_looming_talent_shortage

GEMI. (1998). Environment: Value to Business. Washington D.C.: The Global Environmental Management Initiative. Retreived from http://www.gemi.org/toolmatrix/ToolMatrixItem.aspx?i=10

GEMI. (2001). Environment: Value to the Top Line. Washington D.C.: The Global Environmental Management 
Initiative. Retreived from http://www.gemi.org/toolmatrix/ToolMatrixItem.aspx?i=59

GEMI. (2004). Clear Advantage: Building Shareholder Value. Washington, D.C.: The Global Environmental Management Initiative. Retreived from http://www.gemi.org/resources/gemi\%20clear\%20advantage.pdf

Gjølberg, M. (2013). Nordic Companies-Global Pioneers in CSR: The Past and the Future for the "Nordic model of CSR”. In A. Midttun (Ed.), CSR and beyond: A Nordic Perspective. Oslo: Cappelen Damm AS.

Glaser, B., \& Strauss, A. (1967). The Discovery of Grounded Theory: Strategies for Qualitative Research. Chicago: Aldine.

Greening, D. W., \& Turban, D. B. (2000). Corporate social performance as a competitive advantage in attracting a quality workforce. Business \& Society, 39(3), 254-280. http://dx.doi.org/10.1177/000765030003900302

Haanaes, K., Arthur, D., Balagopal, B., Kong, M. T., Reeves, M., \& Velken, I. (2011). Sustainability: The 'Embracers' Seize Advantage. Boston: MIT Sloan Management Review and the Boston Consulting Group. Retreived from http://c0426007.cdn2.cloudfiles.rackspacecloud.com/MIT-SMR-BCG-sustainability-the-embracers-sei ze-advantage-2011.pdf

Hart, S. L., \& Milstein, M. B. (2003). Creating sustainable value. Academy of Management Executive, 17(2), 56-69.

Huselid, M. A., Beatty, R. W., \& Becker, B. E. (2005). “A Players” or “A Positions”? Harvard Business Review, December, 110-117.

Insurance Daily. (2012). Insurance CEOs hampered by talent shortage. Retrieved from http://www.insurancedaily.co.uk/2012/02/25/insurance-ceos-hampered-by-talent-shortage/

Insurance Journal. (2013). The Next Generation. Retrieved from http://www.insurancejournal.com/magazines/features/2013/04/08/286902.htm

Jones, D., Willness, C., \& Madey, S. (2013). Why are Job Seekers Attracted by Corporate Social Performance? Experimental and Field Tests of Three Signal-Based Mechanisms. Academy of Management Journal, 56(2), 1-6. http://dx.doi.org/10.5465/amj.2011.0848

Kim, C. H., \& Scullion, H. (2011). Exploring the links between corporate social responsibility and global talent management: a comparative study of the UK and Korea. European Journal of International Management, 5(5), 501-523. http://dx.doi.org/10.1504/EJIM.2011.042176

KPMG. (2012). Insurance Industry Outlook Survey: Executives Focus on Efficiency, IT, and Talent amid Slow Growth and Regulatory Challenges. New York: KPMG LLP (KPMG). Retreived from http://www.kpmg.com/US/en/IssuesAndInsights/ArticlesPublications/Documents/2012-insurance-outl ook-survey.pdf

Kvale, S., \& Brinkmann, S. (2009). Interviews: Learning the Craft of Qualitative Research Interviewing (2nd ed.). Thousand Oaks: SAGE Publications, Inc.

Lamb, M., \& Sutherland, M. (2010). The components of career capital for knowledge workers in the global economy. The International Journal of Human Resource Management, 21(3), 295-312. http://dx.doi.org/10.1080/09585190903546839.

Lane, K., \& Pollner, F. (2008). How to Address China’s Growing Talent Shortages. The McKinsey Quarterly, 3, 33-40. Retreived from http://www.mckinseychina.com/wp-content/uploads/2008/07/hoad08.pdf

Lengnick-Hall, M. L., Lengnick-Hall, C. A., Andrade, L. S., \& Drake, B. (2009). Strategic human resource management: The evolution of the field. Human Resource Management Review, 19(2), 64-85. http://dx.doi.org/10.1016/j.hrmr.2009.01.002

Lewis, R. E., \& Heckman, R. J. (2006). Talent management: A critical review. Human Resource Management Review, 16(2), 139-154. http://dx.doi.org/10.1016/j.hrmr.2006.03.001

Lovins, A. B. (2007). Getting of oil. Retrieved from http://www.rmi.org/Knowledge-Center/Library/E06-08_GettingOffOil

Magnúsdóttir, G. L. (2009). Small States' Power Resouces in EU Negotiations-The Cases of Sweden, Denmark and Finland in the Environmental Policy of the European Union. Reykjavík: University of Iceland, Department of Political Science. 
Mcdonnell, A. (2011). Still Fighting the "War for Talent"? Bridging the Science Versus Practice Gap. Journal of Business and Psychology, 26(2), 169-173. http://dx.doi.org/10.1007/s10869-011-9220-y

McDonnell, A., Lamare, R., Gunnigle, P., \& Lavelle, J. (2010). Developing tomorrow's leaders-Evidence of global talent management in multinational enterprises. Journal of World Business, 45(2), 150-160. http://dx.doi.org/10.1016/j.jwb.2009.09.015

Meyers, C. M., van Woerkom, M., \& Dries, N. (2013). Talent—Innate or acquired? Theoretical considerations and their implications for talent management. Human Resource Management Review, 23(4), 305-321.

Network for Business Sustainability. (2010). The New Normal: Perspectives from Students on How Organizations Can Be More Sustainable. London, Ontario: Network for Business Sustainability. Retreived from http://nbs.net/wp-content/uploads/new_normal.pdf

Norden. (2010). The Nordic Region: A Green Climate Leader. Programme for the Finnish Presidency of the Nordic Council of Ministers 2011. Copenhagen: Nordic Council of Ministers. Retreived from http://www.norden.org/en/publications/publikationer/2010-768

Nordic Council of Ministers. (2009). Nordic climate co-operation. Retrieved from http://www.norden.org/en/areas-of-co-operation/climate

Penn Schoen \& Berland Associates, Burson-Marsteller, \& Landor. (2009). Corporate Citizenship Study. Retrieved

from

http://www.burson-marsteller.com/Innovation_and_insights/blogs_and_podcasts/BM_Blog/Document s/Corporate\%20Citizenship\%20Executive\%20Summary.pdf

Porter, M. E., \& van der Linde, C. (1995). Green and Competitive: Ending the Stalemate. Harvard Business Review, September-October, 120-134.

PricewaterhouseCoopers LLP. (2011). The insurance industry in 2011. Top issues-An annual report, 3, 1-30. Retreived

from http://www.pwc.com/us/en/insurance/publications/assets/top-insurance-industry-issues-2011.pdf

PricewaterhouseCoopers LLP. (2012). The insurance industry in 2012. Top issues-An annual report, 4, 1-35. Retreived

from http://www.pwc.com/en_US/us/insurance/publications/assets/pwc-top-insurance-industry-issues-2012. pdf

PwC. (n.d.). Concerns over talent shortages. Retrieved from http://www.pwc.com/gx/en/ceo-survey/2012/industry/insurance.jhtml

Quigley, N. R., \& Tymon Jr, W. G. (2006). Toward an integrated model of intrinsic motivation and career $\begin{array}{llll}\text { self-management. Career Development International, } & \text { 11(6), }\end{array}$ http://dx.doi.org/10.1108/13620430610692935.

Risk Management. (2013). How Insurance Companies Can Become Good Corporate Citizens. Retrieved from http://www.rmmagazine.com/2013/07/01/how-insurance-companies-can-become-good-corporate-citiz ns/

Rupp, D. E., Ganapathi, J., Agulera, R. V., \& Williams, C. A. (2006). Employee reactions to corporate social responsibility: an organizational justice framework. Journal of Organizational Behaviour, 27(4), 537-543. http://dx.doi.org/10.1002/job.380

Saks, A. M. (2005). The Impracticality of Recruitment Research. In A. Evers, N. Anderson, \& O. Voskuijl (Eds.), The Blackwell Handbook of Personnel Selection (pp. 47-72). Malden, MA: Blackwell.

Scullion, H., \& Brewster, C. (2001). The Management of Expatriates: Messages from Europe? Journal of World Business, 36(4), 346-365. http://dx.doi.org/10.1016/S1090-9516(01)00060-8.

Spencer Stuart. (2007). Talent management and succession planning in the European insurance industry. Spencer Stuart.

Stahl, G. K., Björkman, I., Farndale, E., Morris, S. S., Paauwe, J., \& Stiles, P. (2007). Global talent management: How leading multinationals build and sustain their talent pipeline. Faculty \& Research Working Paper, INSEAD Working Paper Series 2007/24/OB. Retreived from http://www.insead.edu/facultyresearch/research/doc.cfm?did=2738

Stake, R. E. (1998). Case studies. In N. K. Denzin \& Y. S. Lincoln (Eds.), Strategies of qualitative inquiry. 
Thousand Oaks: SAGE Publications, Ltd.

Strack, R., Caye, J. M., Leicht, M., Villis, U., Böhm, H., \& McDonnell, M. (2007). The Future of HR in Europe: Key Challenges Through 2015. Boston: The Boston Consulting Group. Retreived from https://www.bcg.com/documents/file15033.pdf

Tarique, I., \& Schuler, R. S. (2010). Global talent management: Literature review, integrative framework, and suggestions for further research. Journal of World Business, 45(2), 122. http://dx.doi.org/10.1016/j.jwb.2009.09.019

Taylor, S. J., \& Bogdan, R. (1998). Introduction to Qualitative Research Methods: A Guidebook and Resource (3rd ed.). New York: John Wiley \& Sons, Inc.

The Geneva Association. (2012). The Geneva Association Annual Report-2011/2012. Geneva: The Geneva Association. Retreived from https://www.genevaassociation.org/media/500057/ga2012-annual-report.pdf

The Geneva Association. (2013). The Geneva Association/IIS Research Award Partnership: Call for papers to be presented at the IIS Seminar in Seoul, Korea June 16-19, 2013. Retrieved from http://www.genevaassociation.org/Call_Of_Papers/Shin_Research_Call_for_Papers-Seoul2013.pdf

The Indian Express. (2012). Urgent need to manage talent gap in insurance industry. Retrieved from http://www.indianexpress.com/news/urgent-need-to-manage-talent-gap-in-insurance-industry/1046647

Turban, D. B., \& Greening, D. W. (1996). Corporate social performance and organizational attractiveness to prospective employees. Academy of Management Journal, 40(3), 658-672.

Tymon, W. G., Stumpf, S. A., \& Doh, J. P. (2010). Exploring talent management in India: The neglected role of intrinsic rewards. Journal of World Business, 45(2), 109-121. http://dx.doi.org/10.1016/j.jwb.2009.09.016

Vaiman, V. (2010). Managing talent of non-traditional knowledge workers - opportunities, challenges, and trends. In V. Vaiman (Ed.). Talent Management of Knowledge Employees: Embracing Non-traditional Workforce (pp. 1-22). Basingstoke: Palgrave Macmillan.

Vaiman, V., Scullion, H., \& Collings, D. (2012). Talent management decision making. Management Decision, 50(5), 925-941. http://dx.doi.org/10.1108/00251741211227663

World Business Council for Sustainable Development. (2010). People Matter. Retrieved from http://www.wbcsd.org/work-program/capacity-building/people-matter/overview.aspx

World Economic Forum. (2011). Global Talent Risk-Seven Responses. Geneva: World Economic Forum. Retreived from http://www3.weforum.org/docs/PS_WEF_GlobalTalentRisk_Report_2011.pdf

Yin, R. K. (2009). Case Study Research: Design and Methods (4th ed.). Thousand Oaks: SAGE Publications, Inc.

Yoder, J., Rao, A., \& Bajowala, M. (2012). PwC Insurance 2020: Turning change into opportunity. New York: PricewaterhouseCoopers International Limited (PwCIL). Retreived from http://www.pwc.com/en_GX/gx/insurance/pdf/insurance-2020-turning-change-into-opportunity.pdf

\section{Copyrights}

Copyright for this article is retained by the author(s), with first publication rights granted to the journal.

This is an open-access article distributed under the terms and conditions of the Creative Commons Attribution license (http://creativecommons.org/licenses/by/3.0/). 